\title{
A COMPREHENSIVE MODEL OF MUNICIPAL HOUSING STOCK MANAGEMENT
}

\author{
Andrzej Muczyński, Ph.D. \\ Faculty of Geodesy, Geospatial and Civil Egineering, \\ University of Warmia and Mazury in Olsztyn, \\ e-mail:amucz@uwm.edu.pl
}

\section{Abstract}

In many European countries there are still substantial housing needs which social landlords have to fulfill. Especially in countries with a shortage of affordable housing for -underprivileged households, the effective and efficient management of the existing social housing stock, which includes technical, social, financial and tenure management activities on the strategic, tactical and operational level, is very important. The paper presents a comprehensive model of municipal housing stock management in the context of Polish conditions. This model was built by adapting the multidimensional concept of real estate management originally developed for commercial real estate portfolio management. It shows an integrative view of municipal housing stock management in Poland and contributes to the better organization and coordination of management activities and tasks in this area. The prepared model may be of interest to other countries where the functions of social landlords are mostly carried out directly by municipalities and their organizational units.

Keywords: Poland, municipal housing, comprehensive model, management levels and perspectives.

JEL Classification: O18, R31, R38.

Citation: Muczyński A., 2016, A Comprehensive Model of Municipal Housing Stock Management, Real Estate Management and Valuation, Vol. 24, No. 2, pp. 57-71.

DOI: $10.1515 /$ remav-2016-0014

\section{Introduction}

The term "social housing" has no unequivocal definition in the European context. Its meaning varies across nation states and time. Social housing in Europe emerged as an instrument to tackle the massive housing shortage, resulting first from the mass industrialization and urbanization processes taking place in the beginning of the twentieth century, and later as a consequence of the destruction following the Second World War. In both cases, the target population were not always the poorest households, but the better-off working class and middle-class households. Nowadays, however, social housing faces very different challenges. Since the middle of the 1970s in Western Europe (and since the 1990s in countries in transition), housing has become increasingly market-oriented, competitive and open to economic pressures. Investment in new social housing in many countries decreased in real terms. This fact, together with the privatization social housing which took place in some countries, has resulted in the reduction of the share of social housing in total housing. Consequently, there is a trend towards tenure segmentation by income, with an increase in the number of lowincome households in the social rental sector across Europe. This has brought about social and spatial polarization and segregation (UNECE, 2006).

The paper presents a comprehensive model of municipal housing stock management in the context of Polish conditions. This model was built by adapting the basic concept of real estate management originally developed for commercial real estate (portfolio) management by KÄMPF-DERN and PFNÜR (2009). The model shows a multidimensional and integrative view of municipal (social) housing stock management in Poland and contributes to the better organization and coordination of management activities and tasks in this area. The prepared model may be of interest to other countries with a local- 
government-dominated social rented sector, where social landlords' functions are mostly fulfilled directly by municipalities and their organizational units. The results of own research and the analysis of literature on the subject were used in its creation.

\section{Social housing management - literature review}

Many authors have analyzed the development of the social housing sector in the old member states of the EU (e.g OXLEY and SMITH 1996; PRIEMUS and DiELEMAN 1997; 2002; BOELHOUWER et al., 1997; Priemus et al., 1999; BOELHOUWER, 1999; HeIJDEN 2001; WHITEHEAD, 2003; KING, 2006) as well as in the new ones (e.g. MANDIČ, 2000; LUX, 2003; DONNER, 2006; TSENKOVA, 2009; LIS, 2011; HEGEDÜS and TELLER, 2013; MUZIOŁ-WĘCŁAWOWICZ, 2013) pointing to the wide range of differences as well as similarities. Much has been written in literature about the need for and definition of social housing. MACLENNAN and MORE (1997) claim that social housing is needed when the socially desired needs for housing exceed the effectively desired demand for housing. In general, it is agreed that this means affordable housing for vulnerable groups of people. A review of literature produces various definitions of social housing (e.g. OXLEY, 2000). What is noticeable is that views are far from unanimous. There are also different typologies for social housing in Europe (HARLOE, 1995; KEMENY, 1995; GHEKIE`RE, 2007). Despite general difficulties in defining social housing, HARLOE (1995) points out two essential characteristics: it is provided by landlords that are not profit-motivated and is administratively allocated according to "need". Nowadays, social housing in Europe is a combination of public housing stock (owned and managed by central or local governments, depending on the country) and a range of voluntary or not-for-profit associations and foundations, public or private notfor-profit companies, co-operative organizations and private investors that provide social housing. Although social housing is generally equated to social rental, it also comprises the provision of affordable dwellings for sale to households for ownership (CZISCHKE, 2006). All the concepts mentioned above clarify why it is very difficult to agree on any meaningful common definition of social housing. However, it is possible to identify some core elements of what constitutes social housing across the EU. According to PITTINI and LAINO (2011), social housing provision encompasses the development, renting/selling and maintenance of dwellings at affordable prices, as well as their allocation and management, which may also include the management of housing estates and neighborhoods. Increasingly, management of social housing can encompass social aspects: for example, care services are included in housing or rehousing programs for specific groups, or in debtmanagement for low-income households.

Social housing management is an area of public real estate management strongly dependent on systems and housing policies in the individual countries. In many of them, housing systems are in transition as a part of a general trend towards the privatization, deregulation and decentralization of public tasks. As a result of these changes, social landlords have become more dependent of private capital and are forced to operate in a more business-like way to keep their financiers satisfied (BOELHOUWER, 1999). Thus, the transformations in institutional and economic context have lead to more market-oriented social housing (asset) management (PRIEMUS et al., 1999; LARKIN, 2000). In the past, management of the existing social housing stock consisted, first of all, of day-to-day maintenance and administration. Strategic decisions about investments in the housing stock were made mostly by governments rather than by individual landlords. Now, most housing management in the social rented sector is the responsibility of public, semi-public or private housing managers: housing associations, housing corporations, municipal companies, or local housing authorities. These landlords are faced with the challenge of developing their own strategies (GRUIS et al., 2003) to reorganize their management and to incorporate principles and approaches derived from the private sector, such as strategic business planning, benchmarking and balanced score cards (GRUIS and NIEBOER, 2004b). Social housing management is defined as the set of all activities to produce and allocate housing services from the existing social housing stock (PRIEMUS et al., 1999). Housing management activities consist of a variety of actions, categorized into technical management (maintenance, renovation, etc.), social management (housing allocation, etc.), financial management (treasury, rent policy) and tenure management (letting, buying, selling). Another subdivision of the specified categories is the distinction between day-to-day (operational) and strategic housing management. Strategic housing management sets the priorities and direction for the future. Short-term decisions are reactions to daily problems, but they have to fit in with long-term policies. This distinction can be compared to the distinction made by MiLES et al. (1996) in (commercial) real estate management 
between portfolio, asset and property management. According to (GRUIS and NIEBOER, 2004a), strategic housing management may be placed on the level of asset management, but also contains elements of portfolio management as far as the residential portfolio is concerned.

\section{Basic concept of real estate management}

The main assumptions of the so-called basic concept of real estate management (REM) were first published in the working paper (KÄMPF-DERN and PFNÜR, 2009), and were then detailed in the study (KÄMPF-DERN, 2009). This concept presents the real estate management structure in a multidimensional approach which consists of three core dimensions (inside the "management cube") and two situational ones (outside). The model of a cube represents an integrative view of real estate management and enables the flexible adaptation of the initial construction to specific cases without changing its structure. Three core dimensions characterizing the major aspects of real estate management include criteria such as: the life cycle phase, perspectives of real estate activities and management levels. Simultaneously, to demonstrate specialization and deconstruction between jobs, departments or even companies, one can imagine the cube being split in smaller and smaller cubes, as necessary. Each of the smaller cubes includes management activities, being a specialized part of real estate management, planning, organizing, steering and controlling the lower level's core processes or other management activities. The three-stage division of the cube was introduced only for better visualization; in fact, there are many more subdivisions and the borders between them are seamless. These core dimensions in the "management cube" have been supplemented by situational (or contextual) criteria, including real estate segment (type) and the location of the property. Outside the "management cube", so-called real estate services (RES), which are not treated as management activities, have been additionally highlighted. They cover all core real estate related tasks, which include not only accounting or letting, but also marketing or financing activities, as well as notary, construction or tax consulting services.

\section{Adaptation of the basic concept of REM to municipal housing stock management in Poland}

Adaptation of the above-described concept to social housing stock management and its clarification in Polish conditions requires the presentation of some preliminary remarks concerning the legal and factual framework of the housing sector in Poland. Following the transition from a centrally planned housing policy towards a market-oriented one, the national government withdrew from direct intervention in the housing sector by reducing its competencies to coordinating and supporting housing market development. Simultaneously, as a result of the decentralization of public tasks and communalization of state property, the main responsibility for providing public assistance with regard to housing was transferred to the local authorities. Therefore, they became obliged to conduct their own independent housing policies according to local needs and opportunities within uniform housing market regulations and institutional arrangements established at the government level. The main objectives of these policies include the creation of conditions to satisfy the housing needs of local populations, especially of low-income households and of special care groups (such as the homeless, evicted, disabled, elderly, single mothers, etc.). These objectives are achieved by local authorities using mainly their own housing stocks that have been incorporated into communal property through the complimentary transfer from the state sector or acquired later in a different way. It should be noted that covering the greatest housing needs were the municipalities. Therefore, municipal housing stocks (MHS) are, in practice, the basis for the social housing system in Poland. Other sectors of social housing such as housing stocks owned by non-profit housing associations (called TBS's) or by housing cooperatives that are mainly rented out to middle-income households, are still of a relatively minor quantitative importance and, therefore, have been excluded from these considerations.

The MHS consist mainly of rented municipal dwellings, as well as of municipal non-residential premises that are rented for public or commercial purposes. In accordance with regulations regarding the protection of tenants' rights, rental agreements for dwellings from this stock should only be concluded for an indefinite period. The exception are sub-standard dwellings (intervention dwellings for the poorest or evicted), which are rented for a specified period (usually for one year), with the possibility of extending this period after the tenant has fulfilled certain criteria. Local authorities, as social landlords, are responsible for defining the terms and procedures of renting municipal 
dwellings, particularly for defining the target groups that can apply to rent these dwellings as well as for deciding about the potential tenants' income limits and about other accessibility criteria to these housing stocks. As a result of the extensive privatization of municipal dwellings, the discussed MHS's are divided into two segments (Fig.1). The first one includes municipal dwellings located in buildings that are the exclusive property of local authorities. Here the municipality (as the only owner) has a high autonomy in decision-making and activities related to real estate management. The second segment covers municipal dwellings located in buildings being of public-private ownership that are independently managed by housing corporations (commonhold associations). In these buildings, the municipality (as one of many property owners) has limited influence on the decisions and management activities relating to the common real estate. Existing limitations of this segment, however, have only an indirect impact on the social landlord's core function performed by the municipality. It can be concluded that the presented framework of MHS creates the possibility for the effective adaptation of the discussed basic concept because the municipalities have real ability to overtake decisions and activities in all major aspects of real estate management.

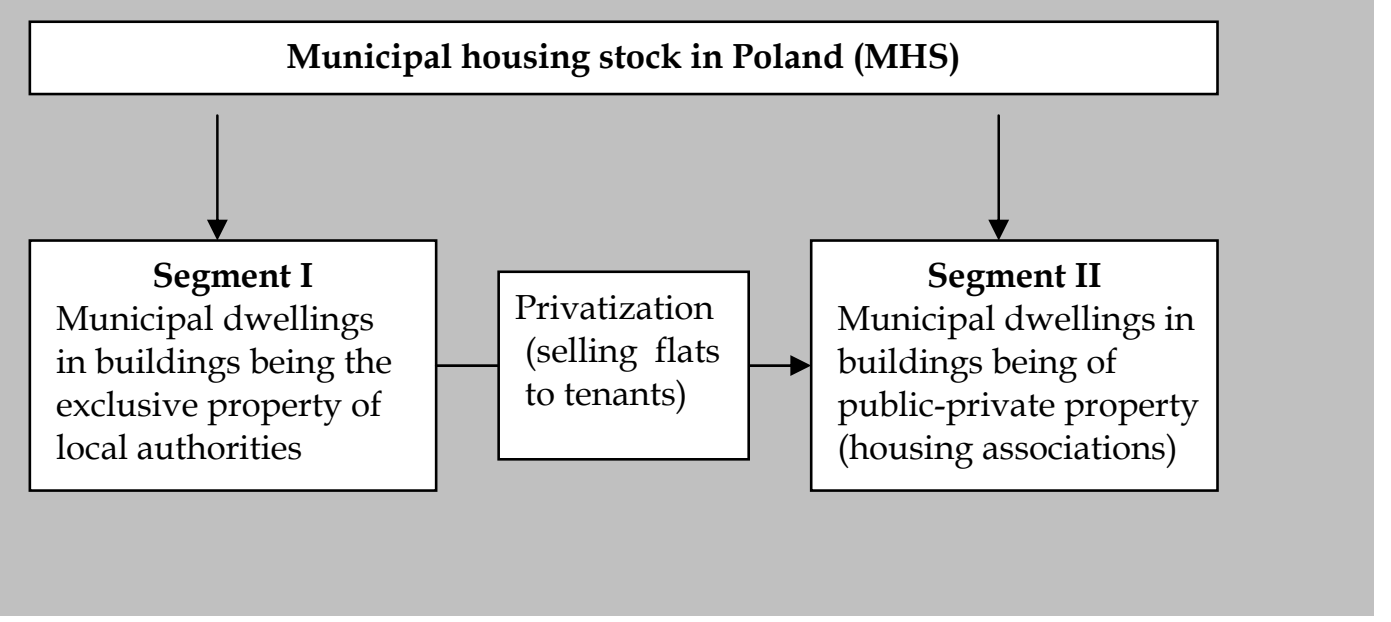

Fig. 1. Structure of municipal housing stock in Poland. Source: Own study.

A proposed comprehensive model of municipal housing stock management has been shown in Fig. 2. In its overall construction, it is based on the structure of the "management cube" used in the mentioned basic concept of REM. Therefore, it is characterized by two contextual (external) and three core (internal) dimensions that have been flexibly adjusted to the specificity of social housing stock management realized by municipalities.

\section{Contextual (external) dimensions of municipal housing stock management}

The development of the model started from establishing its contextual dimensions. To achieve this, important groups of factors which determine municipal landlords' approach towards housing stock (asset) management were identified in the external environment. These groups include factors such as the profile of the national housing system and the conditions of the local housing market. The notion of a housing system is used here as a general term for the entirety of public housing policy, regulations, legislation, financial government support and institutional arrangements, including historic developments (tradition) within the national system (GRUIS et al., 2003). Both groups of variables specify not only the types of landlords operating in the social rented sector (their role, objectives, housing stock, organization and financial position), but also the influence of their market behavior, that is, whether they perform asset management of their housing stock in a more or less strategic (business-like) way. We may expect that social landlords' asset management is more strategic if they operate within a more market-oriented housing system (with fewer regulations, less financial support and a reduced need for new social rented dwellings), whereas under strong government regulation, (through grants, legislation, renewal programs, etc.), there is less possibility and necessity for landlords to create their own policy. Moreover, substantial financial government support gives landlords little incentive for strategic behavior in which they avoid risks and seek opportunities for increasing their financial return. Institutional arrangements can also have consequences for the 
strategic behavior of social landlords. For example, those landlords who operate within an institutional structure in which strategic decisions are made by the government are solely responsible for carrying out the daily management of the (marginal) social housing stock and there is little need here for strategic asset management. It should be emphasized that social landlords who share a significant part of the local housing market, supplying housing services to a diverse group of households, typically operate more strategically to cope with this diversity, which is also reflected in the diversity of the stock. In turn, social landlords who operate a stock of poor quality and/or under difficult financial conditions (due to low rents and limited financial support from government) require a strategic stock management approach to be able to perform their roles as providers of affordable housing (GRUIS et al., 2003).

\section{National Housing System's Profile}

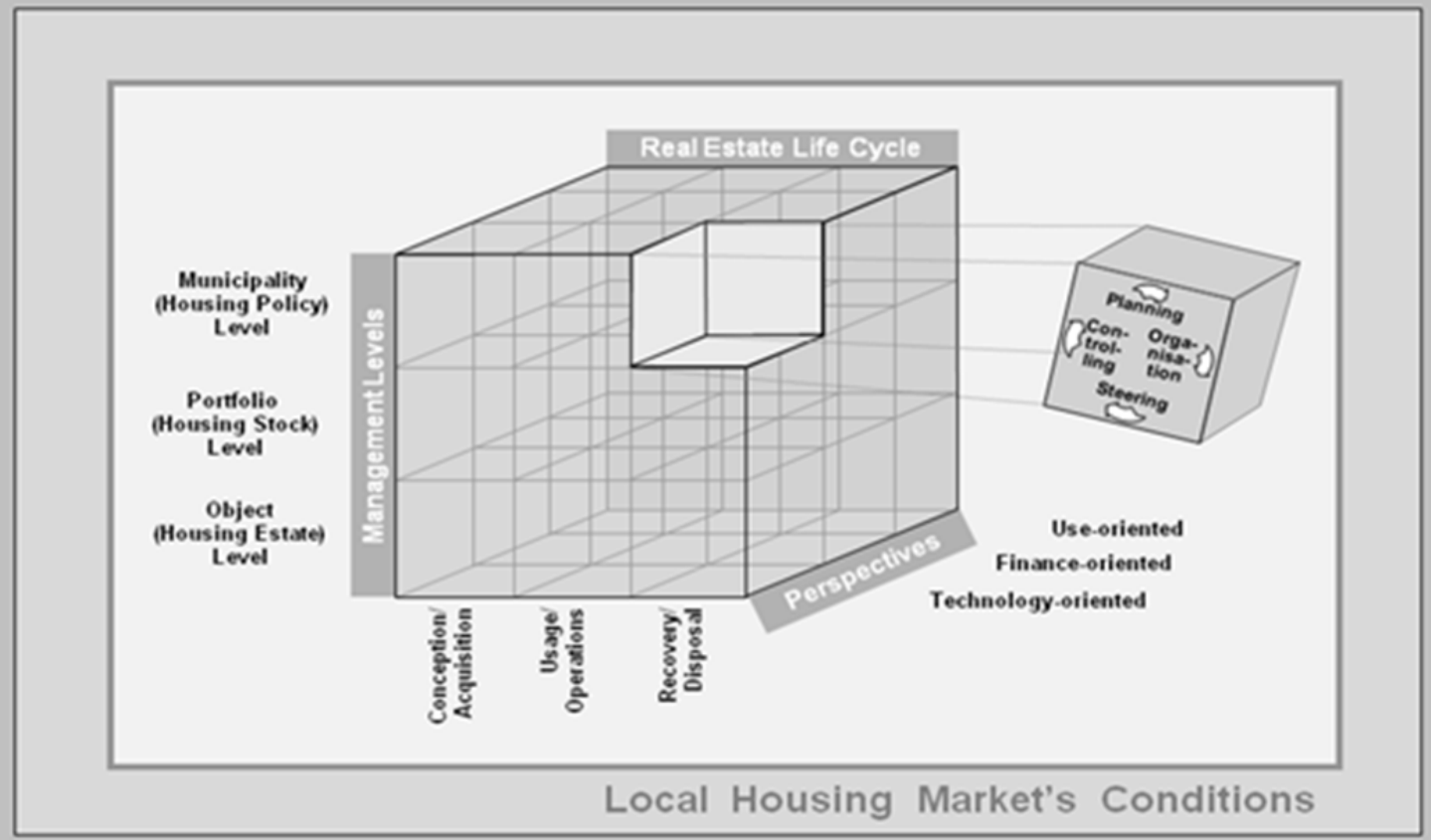

Fig. 2. A comprehensive model of municipal housing stock management. Source: Own study based on Kämpf-Dern and Pfnür (2010).

The Polish housing system is an intermediate system that is closer to the dual than the unitary system according to the distinction made by KEMENY (1995). It is based on a local government dominated social rented sector in which the social landlords' functions are, in the vast majority, filled directly by municipalities. These entities in fact integrate the functions of local authorities with the role of the owner (and provider) as well as the manager of the municipal housing stock allocated to lowincome households or to special target groups, such as the evicted or the disabled. The social rented sector is complemented by a relatively small housing stock owned and managed by non-profit housing associations and housing cooperatives that allocate dwellings to middle-income tenants. Moreover, in large cities, the private (commercial) rented sector is also developing, where housing prices and rents are determined by the market mechanism. The national housing market is characterized by a moderate share of owner-occupied dwellings, which is constantly increasing as a result of both investment processes carried out mainly by private developers and the privatization of public housing (primarily through selling to occupiers) conducted by municipalities, state organizations and housing cooperatives. Government regulations with regard to municipal housing stock are focused on rules for the selection of target groups of tenants and general rent-setting guidelines (in reference to the maintenance and administration costs of property), as well as minimum requirements regarding the quality of rented dwellings (and buildings) in general. Local authorities have relatively large autonomy in rent setting, the sale of and making strategic decisions about investments in the housing stock. Therefore, from this viewpoint, municipal social landlords are 
formally able to pursue a more market-oriented approach towards their asset management. The most important problem arising from legal regulations relating to municipal housing is the strong protection of the current tenants' rights.

This excessive protection efficiently impedes the displacement of tenants between different segments of the housing stock, which is a major barrier to the implementation of more flexible strategic asset management (MUCZYŃSKI and TURBACZEWSKA, 2013). The significant local housing market conditions that have an impact on strategic social landlords' stock management include: social housing needs, the diversity of prices and rents of dwellings, the quality and structure of the existing housing stock, and the general housing shortage within the municipality. In many cities, existing housing stocks are characterized by numerous qualitative and quantitative deficiencies. Municipalities have predominantly old housing stocks that are of poor quality due to significant oversights in carrying out repair and renovation works in the past, while a general shortage of social dwellings is observed on local markets (despite of the still relatively high demand for them for various reasons). In addition, most municipal landlords operate under difficult financial conditions because of the problems associated with collecting rents in practice and relatively high operating costs, as well as due to limited external (governmental) financial support. The financial situation of the municipal landlords is not significantly improved by the rental of non-residential premises, given that their share in individual stocks is relatively small and they are often rented out well below going market rents. This situation is also not significantly improved as a result of the privatization of municipal housing stock, because the revenues from it are relatively low (due to discounts in the sale prices given to the occupiers), and due to the fact that municipal authorities typically use these revenues for purposes not related to housing management. It should also be noted that the increasing dispersion of municipal housing ownership into many public-private housing corporations follows as a result of privatization. Problems associated with mixed-ownership management seriously impede the implementation of the municipalities' own policies regarding asset management in this segment of municipal housing stock. In conclusion, the presented groups of factors and circumstances have an important impact on municipal landlords' approach towards their strategic asset management and, hence, have been included in the contextual dimensions of the municipal housing stock management. The analysis of external dimensions showed that the municipal landlords active in the Polish housing system and under local housing market conditions have some autonomy (potential opportunities and real needs) which would allow them to develop more market-oriented asset management as opposed to traditional task-oriented asset management. The implementation of this approach is limited primarily by the excessive protection of the tenants' rights, which prevents the efficient allocation of existing housing stock. It should be remembered that municipal housing stock management is not implemented in isolation (PRIEMUS et al., 1999). There are many relationships and interdependencies with a number of stakeholders, such as tenants, householders looking for a new dwelling, housing organization employees, local authorities, the Ministry of Infrastructure and financial (support) organizations. Furthermore, other urban housing stocks managed by non-profit housing organizations, housing cooperatives and commonhold associations (condominiums), as well as private rented housing stocks, have an indirect impact on these processes.

\section{Core (internal) dimensions of municipal housing stock management}

The presented structure consisting of three internal dimensions originally established for the management of investment real estate portfolios can be flexibly adapted to the management of municipal housing stocks. This adaptation should take into account the specificity of municipal housing stock management, including the specific mission and predominant goals of municipal landlords, as well as the existing legal and factual limitations. The three core dimensions characterizing the major aspects of municipal housing stock management therefore refer to such criteria as: the life cycle phases of housing estates, management perspectives and management levels.

\subsection{Life cycle phases of housing estates as a dimension of municipal housing stock management}

The life cycle of a residential property (a dwelling or a building) in the housing stock begins at the phase of conception and acquisition. Social housing should be developed in the long term, and its effective supply depends on a clear and well-structured set of institutional arrangements, as well as understood and coordinated links between the different participants. It should be noted that local authorities play a critical role in this process, specifically in the following: provision of land, land-use 
planning, providing infrastructure and supporting sustainability requirements, securing other social policy objectives and encouraging the involvement of local communities in influencing development proposals (UNECE, 2006). According to the legal regulations in Poland, the acquisition of dwellings for municipal housing stock can be done in various ways, among which we can mention the new construction of municipal buildings or the purchase of completed buildings on the market, as well as the adaptation of vacant or non-residential premises for housing purposes. Besides, social landlords can consider the option of dwellings' sublet by the municipality for its tenants in the private or cooperative sector. The acquisition of dwellings by municipalities, therefore, requires a thorough assessment of the scale of the local community's social housing needs and choosing the most effective ways to satisfy them. In social housing planning, local authorities should focus on the whole-life costs of construction methods and materials to reduce long-term maintenance costs. Municipal housing construction is mainly carried out by the private sector, under contract with developers, and sometimes comes to broader agreements for public-private corporations. Construction of new social housing and some renovations of existing stock are partially subsidized by the government.

In the second phase of the usage and operation, existing housing stock are managed day-to-day (administrated), and individual buildings are regularly used and operated. Within this phase, current management activities are to be effectively carried out, including the collection of rent and covering operating costs, tenants' allocation, and letting of vacant units, maintenance, renovation and modernization of the estates in the stock. It is important to distinguish clearly which specific activities are to be performed on each of the management levels and which parties are responsible for them. This concerns especially the distinction between operational and strategic management activities. Moreover, the way in which the supervision and control of the landlords has been organized is of great importance because it determines their freedom to pursue their own policies (BOELHOUWER, 1999). In Polish circumstances, the day-to-day management of activities on the lowest level can be performed directly by municipal organizational units (companies or budget units), or can be contracted out to non-profit housing organizations or private firms with the capability of acting as professional managers (MUCZYŃSKI, 2013), while the strategic planning, funding, procurement, as well as supervision of these works are the tasks of the municipality (at the top or middle level of this organization) as the owner of the physical housing stock. In the second segment of the MHS comprising mixed-ownership housing stocks, the supervision functions are performed independently by commonhold associations. Here, the operational management services in practice are realized mostly by private firms.

The last phase can be referred to as the phase of recovery and disposal of the existing estates in the considered housing stock. In Poland, the recovery rate of dwellings from the municipal housing stocks for their repeated rental to other occupants is relatively low (about 1-2\% per year). This is due to the fact that, even when the tenants' financial standing improves, they do not have to vacate the occupied dwellings. There are legal regulations that enable them to continue staying in these dwellings on the existing terms because the municipal landlords cannot verify the tenants' financial standing during the term of agreements concluded for an indefinite period of time. Therefore, the majority of municipal dwellings are no longer temporary and accessible and, instead of serving the original purpose for which they have been built and maintained, bring undue profits to their current tenants who can often afford to purchase or rent a dwelling on the market. It is almost impossible to recover such dwellings because, very often after the tenant's death, the right to rent is transferred directly to their family members, disregarding the fact that their material status does not meet the vital requirements. As a result, the number of recovered municipal dwellings is insufficient to satisfy the needs of those lowincome families who are in real need of housing assistance from local authorities. Under these circumstances, in most municipalities, the extensive disposal process of municipal dwellings from the existing stocks by selling them to their current occupiers has been realized at preferential (heavily discounted) prices. The privatization process, considered as a way to avoid increasing maintenance costs and high expenditure on the repairs and renovation of municipal housing stocks, was generally implemented by municipalities in a non-systematic method. This led to the mentioned dispersion of municipal housing ownership into many public-private housing corporations (condominiums), which has a significant impact on the management of a large part of these stocks at all phases, perspectives and levels. 


\subsection{Different perspectives of municipal housing stock management}

The second dimension of the model represents the different perspectives of municipal housing stock management, which arise from diversified viewpoints and priorities of various, functionally specialized actors (departments) involved in the entire management process. An important feature of real estate management over other management disciplines is namely the fact that management activities related to a single and same building of experience are performed to reach different goals. This creates different perspectives of management, which have large dependencies between them, but each requires a different concept to achieve these goals (KÄMPF-DERN and PFNÜR, 2009). Therefore, the second dimension of the prepared management model has been divided into three perspectives, which have been named as: technology-oriented, finance-oriented and use-oriented.

The Technology-oriented perspective focuses on providing (building) housing facilities to the municipal housing stock, and then on the maintenance, renovation and improvement of the technical condition of existing buildings in the stock, and, finally, on the recovery of destroyed buildings or disposal of superfluous ones from this stock. Management activities in this perspective are performed with the goal of optimizing quality, costs and deadlines while carrying out the work. Housing estates are the output of the transformation process here (including land, buildings and infrastructural facilities), meaning spaces of a certain quality designated for residential purposes at any time when needed. In this perspective, the core activities such as the design, construction and operation of housing estates are determined by the architectural and technical conception of property and their operation. Actors whose main business purpose is located in this area usually include such entities as: project developers, project managers, architects, planners, builders or housing facility managers. From this perspective, the project and process management of planning and construction are important concepts. These types of services in the conception and acquisition phase are planned, funded and contracted out at the top level of the landlord (municipality) organization, and technically coordinated and monitored at the lowest level by the technical departments. With the transition of the housing estate in the usage and operation phase, project management gives way to inventory management, including day-to-day maintenance activities and longer-term cyclic maintenance (major repairs) and renovations. Generally, municipal landlords are required to maintain managed housing stocks at a level complying with housing, building, environmental and sanitation codes. Technical departments of municipal landlords are responsible for respective maintenance activities (registration of complaints, breakdowns and commissioning), re-let maintenance (repairs) and planned preventive maintenance activities according to long-term maintenance plans and yearly activity plans. In particular, their main tasks in this regard include conducting technical inspections on a regular basis. When performing these inspections, particular attention should be paid to safety and human health, which is always the overriding priority; hence, the main needs and challenges in this field include checking the general technical condition of buildings, premises and equipment, as well as the state of such installations as: electrical, gas, ventilation, fire safety, plumbing, heating and lift systems. Minor maintenance activities are carried out by qualified staff from technical departments, while more serious or more specialized ones are outsourced to licensed and insured contractors. Major repairs and renovations are, in fact, performed to a relatively small degree due to limited refurbishment grants from the local authorities and from the external financing sources. The majority of the time, minor repairs are done on selected housing estates from these stocks when they can no longer be avoided. This practice, unfortunately, results in the continuous expansion of the gap in repairs of municipal housing stock. Finally, in the recovery phase of housing properties, demolition management becomes important. Because of financial restrictions in this phase, such activities as: demolition, restoration, redevelopment or enlargement of the municipal housing estates are also carried out very rarely. Consequently, the share of sub-standard dwellings in municipal housing stocks is rising (with deteriorating physical condition and increasing stigmatization), which normally should be withdrawn from exploitation but, due to the lack of possibilities of displacing their current occupiers to substitute dwellings, are still used out of necessity. The technology-oriented perspective of municipal housing stock management presented here is interdependent, on the one hand, with the finance-oriented perspective through maintenance and repair budgets, and on the other hand, with the use-oriented perspective through the creation of specific physical characteristics of buildings and dwellings (defining housing quality).

The finance-oriented perspective of municipal housing stock management, in a broader sense, 
includes all the issues and financial problems occurring in all life cycle phases of housing estates from these stocks, including new construction and acquisition of existing dwellings, maintenance and renovation (main repairs), as well as their demolition or disposition. In a narrower sense, according to GRUIS et al. (2003), this perspective can exclude activities which do not affect the characteristics of the physical housing stock (e.g. treasury management and financial business administration). Priorities of this perspective in the commercial (private rented) sector are related to financing investment in real estate, thus management activities are performed from the viewpoint of capital investment with the goal of optimizing return, risk and liquidity stemming from real estate investments. However, in the social rented sector, financial priorities are significantly determined by the social aspects of managing this type of assets, which are connected with the effective provision and efficient letting of decent, affordable dwellings to special (e.g. most vulnerable or disadvantaged) target groups of households. Therefore, as NIEBOER and GRUIS (2006) note, the specific characteristics (and tasks) of social landlords and government regulation of the social rented sector do not allow social landlords to behave like commercial enterprises and, of course, the role of municipalities in this respect cannot be equated with the role of capital with investors on the real estate market. Hence, optimizing financial performance in social housing stock management is not the primary decision-making criteria and financial returns are important but secondary goals of management activities. This applies in particular to the situation in Poland, where social housing is provided directly by local authorities (municipalities) and these stocks are mostly managed by their organizational units. Nevertheless, more finance-oriented management of social housing stock within the permissible boundaries could bring significant benefits not only to the landlords but also to the entire local community. It is about creating such a portfolio by social landlords which, on one hand, would be more effective in meeting housing demands and the current tenants' preferences, and, on the other hand, would be more economically efficient by providing additional revenue to finance the core social housing stock. The most important elements of the finance-oriented perspective of social housing management include methods and forms of financing (or supporting) new construction, acquisition and renovation of social dwellings (own funds and surpluses, grants, public loans, mortgages, building subsidies etc.), renting policy (rent setting, differentiation and collection), financing and distribution of running costs, subsidization of tenants (housing allowances), as well as the volume of revenues generated from the sale of the disposed dwellings from the stock that are intended to finance the maintenance and renovation costs in the remaining social housing stock. It should be noted that an important factor in this perspective is also the availability of land at discounted prices, as well as tax privileges for social housing providers. With regards to the latter, they include a variety of exemptions or tax rate reductions to providers, for example income and investment deductions, depreciation allowances, reduced property taxes, exemptions from capital gains tax, and a reduced VAT rate (PITTINI and LAINO, 2011). In Poland, the expansion of municipal dwelling stock through new construction and acquisition of existing dwellings is financed mainly from local authorities' budgets. Furthermore, municipalities can also apply for subsidies from a public bank for the construction and renovation of social rented dwellings for the poorest, the homeless and people with special needs (so-called protected dwellings). Rents in municipal dwelling stock are set at the local authority level based on construction costs (replacement value) of housing estates. Since 2004, municipalities have had autonomy to establish the free-market rent, but if it exceeds $3 \%$ of the replacement value of the dwelling, then the increase of rent must be justified in writing. Rents are differentiated by the municipalities on the basis of functional diversity and localization quality of dwellings (and buildings) in the existing housing stock. In the case of social dwellings of a reduced standard provided by municipalities, rents do not exceed $50 \%$ of the lowest rent in municipal housing stock. In practice, communal councils are reluctant to raise rents for social and political reasons, so that their average level in many municipalities, until recently, did not exceed $1.5 \%$ of the replacement value per year. After the recent increases in rents in many larger municipalities (related to the possibility of reducing rents for the poorest tenants), rental income generated by municipal landlords should, in principle, already cover their running costs, including basic operations and maintenance costs. In many cases, however, there are significant problems with balancing income and costs due to the tenants' payment arrears, both in terms of rents and exploitation costs of dwellings. Rental income from non-residential premises coexisting in municipal housing properties only slightly improves the financial situation of many landlords. As mentioned, their current share in many municipal stocks is already small and they 
are often rented well below market rents because of their use for public purposes or due to the lack of an adequate indexation of rent fixed in earlier tenancy agreements. In practice, revenues generated from the sale of dwellings from the stock are also relatively small due to largely discounted sale prices of dwellings for the occupiers. Because of these problems, in many cases the expenditures on minor (and major) repairs in existing housing stock need to be subsidized from the budgets of local authorities. Burdens paid by tenants are eased by housing allowances that are financed by the local authorities and paid directly to the municipal landlords. Because of the large number of beneficiaries of housing allowances from various urban housing stocks, their values are quite low. This means that, despite the financial burden of local authorities, the real impact of these subsidies on the revenues of municipal landlords is very limited.

In general, the use-oriented perspective of MHS management focuses on the contribution of housing estate space for ensuring its operational performance to create appropriate housing conditions for users living in such stock with the aim of optimizing the cost-benefit relation of this contribution. In particular, the predominant goal of the management activities carried out in this perspective is the optimal use of municipal housing stock for the specific core business conducted on it, which includes meeting the housing needs of each group of occupiers of social rented buildings and dwellings. This perspective is based on the creation of adequate housing quality that is a complex concept determined by the legal regulations and guidelines of local housing policy. Housing quality is defined as the physical characteristics of a dwelling which are relevant to the use of that dwelling, including the plan features and facilities provided (STRAUB and VIJVERBERG, 2004). Plan features are such which are determined by the building structure and layout of the floor plan of the dwelling in question, e.g. the volume and floor space, the number of rooms and their size and layout in relation to each other, internal and external accessibility, and outside areas (balcony, loggia, garden). Facilities include the standard of equipment and finishing of the kitchen, bathroom and toilet, as well as heating and hot water installations, electrical systems, lighting and communication. Other determinant factors include the type of dwelling (single-family and multi-family), and the year of construction and tenure. Polish municipalities have predominantly old multifamily housing stocks that are mostly of poor quality due to the significant negligence of repairs and modernization in the past. Taking into account the tenants' material situation and the quality of satisfying housing needs, we can divide the MHS in Poland into the following sectors: nightshelters and homes for the homeless, sheltered dwellings, temporary premises, and social dwellings and full-value municipal dwellings. Nightshelters and homes for the homeless provide beds for one night or for several days to the homeless. A nightshelter is a building or a part of a building designed to provide beds for homeless people, together with the technical facilities necessary for the operation of a nightshelter. A home for the homeless, on the other hand, is a building or a part of a building designed to provide 24-hour accommodation to the homeless, together with the technical facilities necessary for the home to operate properly. Sheltered dwellings are a form of social assistance where specialists teach tenants to live independently, or where 24-hour care is provided to disabled tenants. Rooms and facilities in these dwellings are designed to fit the basic requirements and abilities of the tenants. A sheltered dwelling must accommodate at least three residents, and its minimum usable space cannot be less than $12 \mathrm{~m}^{2}$. Apart from bedrooms, such a dwelling has a kitchen, bathroom and a toilet as well as a common room for social activities. The rooms must be large enough for tenants getting around on wheelchairs to maneuver freely. The function of temporary premises is to give a municipality the opportunity to evict those tenants who are no longer entitled to social or substitute dwellings. These premises must be suitable for living in, must have access to a water supply and a toilet inside or outside the building, must have access to natural light and electrical lighting, and should be heated. Its internal walls cannot be damp and they must be fit for installing cooking facilities. Also, the habitable space must amount to at least $5 \mathrm{~m}^{2}$ per one person. In turn, so-called social dwellings are defined as habitable units with regard to their equipment and technical condition, with a living space of no less than $5 \mathrm{~m}^{2}$ per person in the tenant's household (and $10 \mathrm{~m}^{2}$ in case of a single person household). Such dwellings are often of very low quality and are interventionally allotted to people with the lowest income who have been evicted from other dwellings. Finally, full-value dwellings constituting a predominant part of municipal housing stock usually have a low quality of space, equipment and finishing that is comparable (or sometimes lower) to the standard of dwellings in other urban housing stock built in a similar period and technology. It should be stressed that the rules of using these full-value municipal dwellings are far from flexible. This is due to the aforementioned protection of the current tenants' rights, especially due 
to almost automatic entitlement to tenant's rights of other members of the original tenants' families after their death. This, of course, severely reduces the efficient allocation of these dwellings to tenants who are in real need of housing.

The described perspectives are at the core of municipal housing stock management, because they focus on activities and influence decisions. They become more distinct when the activities specialize and are deconstructed. In the area of municipal housing stock, particular emphasis should be placed on the use-oriented perspective. However, in practice, all perspectives should be taken into account simultaneously, because none of them can exist in isolation from the other two. The integration of these three perspectives leads to the explanation of the interdependencies between them, and to the discovery of similarities and transferability, which can improve the efficiency and effectiveness of basic management processes and, thus, all activities undertaken in the municipal housing stock.

\subsection{Organizational levels of municipal housing stock management}

The third dimension differentiates municipal housing stock management activities and tasks between three hierarchical levels by analogy to the typical division into the top, middle and lower level of management applied in practice. The featured management levels and appropriate concepts assigned to them within commercial real estate management are as follows (KÄMPF-DERN, 2009):

1. Investment/Corporate Level: Real Estate Investment Management (REIM),

2. Portfolio Level : Real Estate Portfolio Management (REPM),

3. Building Management Level (day-to-day management) divided into:

a) strategic building management (SOM): Real Estate Asset Management (REAM), and

b) operative building management (OOM): Property Management (PrM) and Real Estate Facility Management (REFM).

The proper adaptation of the hierarchical structure to municipal housing stock management requires the specific objectives and functions fulfilled by this type of real estate resources to be considered. Therefore, by analogy, it is proposed to define the first (top) level of management as the Municipality (Housing Policy) Level, the second as the Portfolio (Housing Stock) Level, and the third as the Building (Housing Estate) Level. During the gradual clarification of the model at each level, relevant management concepts and tasks with regard to Polish conditions were also defined. Particular attention was paid to presenting typical solutions, which may differ in individual municipalities in terms of some organizational details and are constantly evolving.

At the highest level, the REIM in (commercial) real estate management is defined as the framework giving management of real estate portfolios or business areas. It explores real estate-related goals and capabilities of an investor or company, specifies the basis of the fundamental requirements for investment and divestment decisions, and meets the demand for relevant decisions and controls achievement of their implementation. In the area of municipal housing, the core elements of strategic housing (asset) management in Poland are placed at this level. It is determined by the long-term local housing policy, which sets out the directions, ways and forms of supporting all urban housing stocks in the area of a city by the local government, in particular defining the framework rules and priorities of municipal housing stock management. The main actors - normative decision makers at this level are the mayor and the municipal council. With respect to their own housing stock, the city council should adopt the three most important resolutions such as: a long-term municipal housing stock management program, the regulations for renting out municipal dwellings and the sales conditions of municipal dwellings to the occupiers. These resolutions are the main tools of strategic housing management available to the actors. The mentioned long-term housing stock management program is developed obligatorily in all municipalities, in conformity with the Act on the protection of tenants' rights (2001) for a period of at least five years. Specifically, it contains the prognosis of the quantity and technical conditions of municipal housing stock, and an analysis of modernization and renovation needs together with the sources of financing them. The program also presents the forecasted sales level of municipal dwellings in the years to come, the principles of rental policy, forecasted housing stock maintenance costs, as well as the means and rules of managing municipal housing stock and forecasted changes in this field in the years to come. In the other resolutions, formal conditions and decision-making criteria are formulated in relation to access to, use of and exchange of municipal dwellings, as well as the rules regarding their disposal (including discounted price). Framework guidelines resulting from these resolutions are implemented by the mayor while organizing and 
supervising the management process of municipal housing stock at lower levels. The formalized strategic housing management in Polish municipalities is task-oriented and has a partial and reactive nature. The effective implementation of the more market-oriented, comprehensive and proactive approach to municipal housing management at this level is limited by excessive protection of tenants' rights, difficult financial conditions, and the poor quality of the existing stock, as well as by problems associated with mixed-ownership management in many public-private housing corporations.

In turn, REPM on the second level is referred to as derived from the requirements of real estate investment management and strategic management of bundled real estate stocks (portfolios) where the mutual influence of assets and, thus, the composition of the property portfolio has an impact on the overall achievement of targets. The aim of REPM is the development or preservation of success potential through systematic portfolio structuring. For finance-oriented REPM, the predominant goal is to structure the portfolio to optimize the balance between risk, return and liquidity, while for the use-oriented REPM, structuring happens to optimize production or service provision. Portfolio management with respect to the housing stock may include such activities as: structuring the desired mix of housing (dwelling types and prices), analyzing the performance of the residential portfolio and defining, on this basis, the guidelines for operational management, acquisition and disposition of the housing estates in the stock. In the area of municipal housing management, this level was defined as the Portfolio (Housing Stock) Level. In fact, management activities under Polish circumstances so far have little in common with the classical principles of REPM of commercial real estates. Due to legal restrictions and the small scope of investment in municipal housing, the allocation and structuring of the existing housing stocks (portfolios) are very passive, formalized and cover a relatively small scale. Nevertheless, the analytical (conceptual), supervisory and organizational activities performed at this level are crucial to the coherence of the hierarchical structure of municipal housing stock management. Actors operating at this level monitor and analyze the housing needs of the local community and evaluate the state of the municipal housing stock, and develop strategic plans submitting them for approval by the municipal council. Their main activities are focused on ownership supervision on behalf of the municipality (contracting out and controlling services in the area of operational management, maintenance, repair, supplies etc.) and representing the municipal interests in publicprivate housing corporations (second segment). In addition, they perform services in the field of rent management (allocation, rent setting, evictions, execution of receivables, exchange of dwellings, etc.), as well as handling the sales and acquisition processes of municipal dwellings. Management activities at this level are implemented by relevant agencies of the municipality, which includes the budgetary units or departments of the city council office, and certain persons appointed to perform specified functions. It should be emphasized that the activities performed by these actors play a regulative and connective role between the first and third level of municipal housing stock management.

On the third - Building (Housing Estate) Level - typical management activities of the building are performed. According to (KÄMPF-DERN, 2009), in the case of commercial properties, they are divided into strategic (REAM) and operative building management (PrM and REFM). REAM is the strategic management of a housing estate buildings that strives to achieve the goals established during the life cycle phase of usage and operation and at the interfaces to the conception and acquisition phase, as well as to the recovery and disposal phase. Accordingly, REAM develops strategies for existing housing estate buildings and then organizes and controls their implementation. In municipal housing management, REAM is primarily limited to creating and implementing the management plans for each building by property managers, taking into account the guidelines formulated at higher levels of the hierarchical structure. Supervision and control are carried out by representatives of housing estate owners. Operative management of the buildings deals with day-to-day management issues, such as: rent collection, covering operating costs, maintenance, allocation, provision of supplies and services, etc. Although municipal housing stock management works more with use-orientation, it does not yet have, in practice, a separate sphere of services called facility management (REFM), so all operational management tasks of an economic, technical and infrastructural nature are performed directly by property managers. In the first segment of MHS with the exclusive ownership of local authorities, management activities at this level are usually performed directly by municipal organizational units (companies or budget units), while in the second segment of stock with mixed ownership, these activities are more often contracted out to non-profit housing organizations or to private firms. It should be emphasized that the structure of management entities in various cities evolves over time with the increasing degree of privatization of municipal dwellings. 
Key importance in the management system of municipal housing stocks should be assigned to proper coordination between activities performed by relevant actors at different levels, as well as to cooperation between the municipality and the private owners of previously privatized communal dwellings. It can generally be stated that the management activities for different perspectives are similar at each level, but can differ a lot in detail, depending on the different focuses and sets of targets. There are, however, no sharp or explicit borders, neither between the management levels nor between the management perspectives. Depending on the individual situation of the municipality, the configuration differs so that the borderlines are blurred.

\section{Conclusions}

The Polish housing system is based on a local government-dominated social rented sector in which the functions of social landlords are, in the vast majority of cases, fulfilled directly by municipalities. These entities in fact integrate the functions of local authorities with the functions of the owner (and provider) and manager of the municipal housing stock allocated to low-income households or to special target groups, such as the evicted or disabled. In many cities, housing stocks are characterized by numerous deficiencies. For one thing, municipalities predominantly have stock of old dwellings of poor quality due to significant negligence in carrying out repair and renovation works in the past. What is more, a general shortage of social dwellings is observed on many local markets, despite what is still a relatively high demand for them. Municipal landlords usually operate under difficult financial conditions because of the problems connected with collecting rent, relatively high operating costs, and limited external financial support. In addition, extensive privatization has led to the dispersion of municipal housing ownership into many public-private housing corporations, where municipalities have limited influence on decisions and management activities relating to the common housing estates. Under such conditions, the management processes of municipal housing stocks in Poland have become particularly complicated, refer to housing estates in various life cycle phases, take place at multiple levels and from different points of view, and involve many actors pursuing different objectives in the existing legal and market environment.

To sort out this problem and obtain a comprehensive (integrative) view of the situation, the socalled basic concept of real estate management, developed by mentioned authors for portfolios of commercial (and corporate) real estate, was used. Thus, the framework of this concept has been transferred and flexibly adapted to the structure of the municipal housing stock management in Poland. During this adaptation, the specificity of municipal housing stock management was taken into account, including the appropriate mission and predominant goals of municipal landlords, as well as the existing legal and factual limitations. Simultaneously, the established model is supposed to be universal so that it can be applied in a variety of legal and market conditions. The model of municipal housing stock management is also comprehensive, covering existing management activities in a logical, coherent and sustainable way. Further explanation and concretization of this model allows research to identify white spots to be filled in. Its deconstruction also has a practical use because it indicates areas of proper organization and specialization of management activities within each core dimension, as well as their coordination at the interfaces between them, including creating corresponding systems of accounting and controlling, the planning and development of personnel, corporate culture, etc. Thus, there are many specific problems to be solved, hence the present work is only the initial step on the way to structuring and organizing municipal housing stock management as a professional service according to the indications of management science.

\section{References}

Act of 21 June 2001, Act on Protection of Tenants' Rights, Municipal Housing Stock and Changes of the CivilCode (uniform text, 2005, The Journal of Laws No. 31, Item. 266).

Boelhouwer, P., VAN DeR HeIDEN, H., VAN DE VEN, B., 1997, Management of Social Rented Housing in Western Europe, Housing Studies, 12 (4), pp. 509-529.

BoelHouwer, P., 1999, International Comparison of Social Housing Management in Western Europe, Netherlands Journal of Housing and the Built Environment, 14 (3), pp. 225-240.

CZISCHKE, D., 2006, Social Housing in the European Union: Overview of Key Approaches, Trends and Issues, Colloquium proceedings: Current developments in housing policies and housing markets in Europe: implications for the social housing sector, Cecodhas, Brussels. 
Donner, C., 2006, Housing Policies in Central Eastern Europe, Wiena published bc C. Donner.

GHEKIE`RE, L., 2007, The Development of Social Housing in the European Union; When General Interest meets Community Interest, Summary of the Publication, Paris: Dexia Editors.

GRUIS, V., NIEBOER, N., BROWN T., 2003, What determines asset management approaches in the social rented sector, Paper to be presented at the ENHR Conference in Tirana, 26-28 May 2003.

Gruis, V., NiEbOeR, N., 2004a, Strategic Housing Management: An Asset Management Model for Social Landlords, Property Management, No. 22, pp. 201-213.

Gruis, V., Nieboer, N., 2004b, Financial and Social Return in Housing Asset Management, Theory and Practise of Dutch Housing Associations, Paper to be presented at the ENHR Conference in Cambridge, 2nd-6th July 2004.

HARlOE, M., 1995, The People's Home: Social Rented Housing in Europe and America, Oxford: Blackwell.

HegedÜs, J., TelleR, N., 2013, Social Landlords and Social Housing Management Introduction: Trends in Social Housing Management, In: Hegedüs-Lux-Teller (ed): Social Housing in Transition Countries, Routledge.

HEIJDEN, H., VAN DER., 2002, Social Rented Housing in Western Europe: Developments and Expectations, Urban Studies, Vol. 39 (2), pp. 327-340.

KÄMPF-DERN A., PFNÜR A., 2009, Grundkonzept des Immobilienmanagements. Ein Vorschlag zur Strukturierung immobilienwirtschaftlicher Managementaufgaben, In: Andreas Pfnür (Hrsg.), Arbeitspapiere zur immobilienwirtschaftlichen Forschung und Praxis, Band No. 14.

KÄMPF-DERN A., 2009, Immobilienwirtschaftliche Managementebenen und-aufgaben. Definitions- und Leistungskatalog des Immobilienmanagements, In: Andreas Pfnür (Hrsg.), Arbeitspapiere zur immobilienwirtschaftlichen Forschung und Praxis, Band No. 15.

KÄMPF-DERn A., PFNÜR A., 2010, Nomenclature, Scope of Service and Interfaces of Real Estate Investment-, Portfolio-, Asset-, Property and Facility Management Based on the Basic Concept of Real Estate Management, In 17th European Real Estate Society Conference, ERES: Conference, Milan, Italy.

KEMENY, J., 1995, From Public Housing to the Social Market; Rental Policy Strategies in Comparative Perspective, Routledge, London.

KING, P., 2006, Choice and the End of Social Housing, London: The Institute of Economic Affairs.

LARKIN, A., 2000, Asset Management Strategies: A Review of Asset Management Strategies of Housing Associations in England and Social Housing Providers in Australia, Metropolitan Housing Trust / The Housing Corporation.

LIS, P., 2011, Purposes and Instruments of the Social Housing Policy, in: Dzieciuchowicz J. (red.), Contemporary Transformations of Housing Environment - Selected Issues, Wyd. Uniwersytetu Łódzkiego, Łódź.

Lux, M., 2003, Housing Policy: An End or a New Beginning, Budapest: Local Government Initiative, Open Society Institute.

Maclennan, D., More, A., 1997, The Future of Social Housing: Key Economic Questions, Housing Studies, 12(4), pp. 531-547.

MANDIČ, S., 2000, Trends in Central East European Rented Sectors, Netherlands Journal of Housing and the Built Environment, 15, pp. 217-224.

Miles, M.E., HANEY, R.L., Berens, G., 1996, Real Estate Development; Principles and Process (second edition), ULI, Washington.

MuczyńSKI, A., TURBACZEWSKA A., 2013, The Concept of Displacement of Tenants in the Management of Housing Stock, Real Estate Management and Valuation, Vol. 21 , No. 4, pp. 26-35.

MUCZYŃSKI, A., 2013, Systemy i formy zarządzania zasobami mieszkaniowymi gminy miejskiej (Systems and Forms of Municipal Housing Stock Management), Zarządzanie i Edukacja, No. 90, pp. 129-158.

MuzioŁ-WęcŁawowicz, A., 2013, Poland: Old Problems and New Dilemmas, in: Hegedus J., Lux M., Teller N., (red.) Social Housing in Transition Countries, Routledge, New York, London.

Nieboer N., GRUIS, V., 2006, Government Regulation Versus Market Orientation in Social Housing Management, Paper presented at the ENHR conference: Housing in an Expanding Europe: Theory, Policy, Implementation and Participation, Ljubljana, 2-5 July 2006.

OXLey, M., SMITH, J., 1996, Housing Policy and Rented Housing in Europe, London: E\& FN Spon.

OXLEY, M., 2000, The Future of Social Housing, London: Institute for Public Policy Research.

PitTINI, A., LAINO E., 2011, Housing Europe Review 2012. The Nuts and Bolts of European Social Housing Systems, Published by CECODHAS Housing Europe's Observatory, Brussels (Belgium). www.housingeurope.eu/about/observatory. 
PrIEMUS, H., DiElEMAN, F., 1997, Social Rented Housing: Recent Changes in Western Europe-introduction, Housing Studies, 12, pp. 421-425.

Priemus, H., Dielemann, F., 2002, Social Housing Policy in the European Union: Past, Present and Perspectives, Urban Studies, Vol.39, No. 2, pp. 191 - 200.

Priemus, H., Dieleman, F., Clapham, D., 1999, Current Development in Social Housing Management, Netherlands Journal of Housing and the Built Environment, 14 (3), pp. 211-224.

Straub G., VijVerberG, G., 2004, New Strategies for Housing Quality Improvement by Dutch Landlords, in: Open House International, 29 (3), pp. 38-44.

TsenKova, S., 2009, Housing Reforms in Post-socialist Europe. Lost In Transition, Heidelberg: SpringerVerlag.

UNECE, 2006, Guidelines on Social Housing: Principles and Examples, United Nations, New York and Geneva.

WhiteHEAD, C. M. E., 2003, Restructuring Social Housing Systems, In: Forrest R \& Lee J (eds), Housing and Social Change, London: Routledge. 